\title{
Biotransformation of 1,8-cineole, the main product of Eucalyptus oils
}

\author{
Paula Rodríguez \\ Cátedra de Farmacognosia y Productos Naturales \\ Departamento de Química Orgánica, Facultad de Química \\ Universidad de la República \\ Av. Gral Flores 2124, CP 11800 \\ Montevideo, Uruguay \\ Tel: 95829244068 \\ Fax: 95829241906 \\ E-mail: paularod@fq.edu.uy \\ Wilson Sierra \\ Cátedra de Farmacognosia y Productos Naturales \\ Departamento de Química Orgánica, Facultad de Química \\ Universidad de la República \\ Av. Gral Flores 2124, CP 11800 \\ Montevideo, Uruguay \\ Tel: 95829244068 \\ Fax: 95829241906 \\ E-mail: wsierra@fq.edu.uy \\ Sonia Rodríguez \\ Cátedra de Microbiología \\ Departamento de Química Biológica, Facultad de Química \\ Universidad de la República \\ Av. Gral Flores 2124, CP 11800 \\ Montevideo, Uruguay \\ Tel: 95829244068 \\ Fax: 95829241906 \\ E-mail: soniar@fq.edu.uy \\ Pilar Menéndez* \\ Cátedra de Farmacognosia y Productos Naturales \\ Departamento de Química Orgánica, Facultad de Química \\ Universidad de la República \\ Av. Gral Flores 2124, CP 11800 \\ Montevideo, Uruguay \\ Tel: 95829244068 \\ Fax: 95829241906 \\ E-mail: menendez@fq.edu.uy
}

Financial support: CSIC, PDT-DINACYT, PEDECIBA and OPCW.

Keywords: Biocatalysis, Monoterpenes, Eucalyptus, Green Chemistry.

Abbreviations: BG-11: Blue-Green algal (modified)

FID: Flame Ionization Detector

GC: Gas Chromatography

GC-MS: Gas Mass-Mass Spectrometry

LB: Luria Bertani

TLC: Thin Layer Chromatography

The forest industry in Uruguay has grown considerably during the last decade. Eucalyptus plantations account for $\mathbf{7 4 \%}$ of the forested land, with Eucalyptus globulus being the most widely distributed species. This industry is dedicated exclusively to the production of wood without exploiting the by-products (leaves and small branches). Eucalyptus leaves are known to contain important amounts of essential oils composed primarily of 1,8-cineole oxabicyclo[2.2.2] In thine). In biotransformation of 1,8-cineole, is achieved using a native bacterium (Rhodococcus sp.) which was isolated

\footnotetext{
* Corresponding author
} 
from the soil of Eucalyptus forest. A $98 \%$ of bioconversion was achieved. Three different optically pure compounds were obtained, and they were identified as 2-endo-hydroxy-1,8-cineole, 2-exo-hydroxy1,8-cineole and 2-oxo-1,8-cineole.

The development of the forest industry in Uruguay locates it as one of the industrial activities that has increased the most in the last three decades.

Eucalyptus species account for $74 \%$ of the forested area, with Eucalyptus globulus being the main cultivar showing an increase of 264.798 hectares in the period 1975-2003 (MGAP, 2004). This industry is dedicated exclusively to the production of wood or pulp for the paper industry. As a result, no use has been planned for leaves and branches, which are left on the ground. Recent estimations indicate that in Uruguay this discarded material reaches $48.000 \mathrm{Kg}$ per hectare, after the logging of the trees.

Eucalyptus leaves are rich in essential oils (FAO, 1995). These oils have a recognized allelopathic action (Romagni et al. 2000a; Romagni et al. 2000b) for this reason its extraction before returning the leaves to the soil would be an ecologically advisable practice. Eucalyptus essential oil, that is commercialized at a price of U\$S $3.5 \mathrm{Kg}$, can be easily obtained from leaves and branches by steam distillation (Clark, 2000).

The main component of Eucalyptus essential oil in most species is 1,8 -cineole, representing about $70 \%$ of the total oil by gas chromatography (Lawrence, 1997). This monoterpene is easily obtained from the brute essence through precipitation upon cooling (Guenther, 1975). This compound has a market value of U\$S $8 / \mathrm{Kg}$. The oxidized derivatives of 1,8-cineole represent a set of compounds of high potential as chiral synthon for organic chemistry. Besides, several oxygenated terpenes have shown wide utility in the scent industry as a consequence of their fragrances (Asakawa et al. 1988; Genta et al. 2002). Therefore, hydroxylation of 1,8 cineole would increase its market value.

Production of these derivatives implies the stereo specific introduction of molecular oxygen in not activated carbon atoms, which continues to be a challenge in organic synthesis (Liu and Rosazza, 1990; Roberts et al. 2002). The use of microorganism that carries out this type of reactions constitutes an interesting alternative. Microbial hydroxylations have advantages over classic organic synthesis procedures since they are carried out in soft conditions, they use biodegradable reagents and they are generally stereo selective resulting in the production of an optically pure synthon (Faber, 1995).

In addition, the products obtained by this type of methodology can be labelled and commercialized as GREEN products.

In this work the results on the biotransformation of 1,8cineole using a native Rhodococcus sp. strain isolated from soil obtained from beneath Eucalyptus sp. trees are presented.

\section{MATERIALS AND METHODS}

\section{Bacterial strain}

A native Rhodococcus sp. strain was isolated by our laboratory from soil obtained from beneath Eucalytus sp. trees. This strain is maintained in our microbial collection at $-70^{\circ} \mathrm{C}$.

\section{Biotransformations}

Biotransformations of 1,8-cineole were carried out by fermentation under different conditions.

Table 1: Comparison of results obtained with different strains of bacteria for the biotransformation of 1,8-cineole.

\begin{tabular}{|c|c|c|}
\hline Biocatalyst & Products & $\%$ conversion \\
\hline $\begin{array}{c}\text { P. flava } \\
\text { (Carman et al. 1986) }\end{array}$ & $\begin{array}{l}\text { 2S-exo-hydroxy-1,8-cineole } \\
2 R \text {-endo-hydroxy-1,8-cineole } \\
1 S, 4 R \text {-6-oxo-1,8-cineole } \\
\text { lactone }\end{array}$ & $\begin{array}{c}11.3 \\
1.9 \\
6.1 \\
0.9 \\
\text { Total: } 20.2\end{array}$ \\
\hline $\begin{array}{l}\text { Rhodococcus sp. } \\
\text { (Williams et al. 1989) }\end{array}$ & $\begin{array}{l}\text { 2-endo-hydroxy-1,8-cineole } \\
\text { 2-oxo-1,8-cineole }\end{array}$ & $\begin{array}{c}11 \\
7 \\
\text { Total: } 18\end{array}$ \\
\hline $\begin{array}{c}\text { B. cereus } \\
\text { (Liu and Rosazza, 1990) }\end{array}$ & $2 R$-exo-hydroxy-1,8-cineole & $\begin{array}{c}74 \\
\text { Total: } 74\end{array}$ \\
\hline $\begin{array}{l}\text { Rhodococcus sp. } \\
\text { (this work) }\end{array}$ & $\begin{array}{l}\text { 2-oxo-1,8-cineole } \\
\text { 2-endo-hydroxy-1,8-cineole } \\
\text { 2-exo-hydroxy-1,8-cineole }\end{array}$ & $\begin{array}{c}17 \\
56 \\
25 \\
\text { Total: } 98\end{array}$ \\
\hline
\end{tabular}




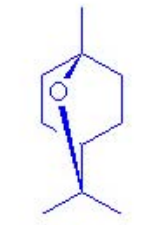

1,8-cineole

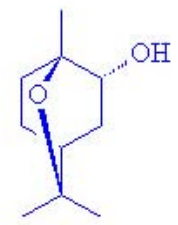

2-exo-hydroxy-1,8-cineole

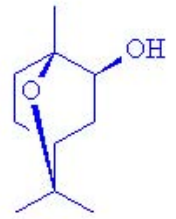

2-endo-hydroxy-1,8-cineole

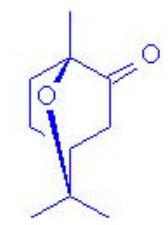

2-oxo-1,8-cineole
Figure 1. Chemical structure of 1,8-cineole and the biotransformation products.

Optimized methodology for biotransformation: Rhodococcus sp. strain was plated in LB and incubated for 5 days at $30^{\circ} \mathrm{C}$. This culture was used to inoculate $50 \mathrm{~mL}$ LB containing $0.1 \%$ cineole and the culture was incubated in an orbital shaker (Sanyo IOX400. XX2. C) at $30^{\circ} \mathrm{C}$ and $200 \mathrm{rpm}$ for 5 days. The cells were washed with BG-11 minimum media and centrifuged at $5000 \mathrm{rpm}$ and $4^{\circ} \mathrm{C}$ for $10 \mathrm{~min}$ (this operation is repeated three times). The obtained pellet was used to inoculate the biotransformation. The biotransformation media used was a modified BG-11 containing $0.1 \% 1,8$-cineole. The variables that were studied comprised the inoculum's size $\left(2 \times 10^{7}, 5 \times 10^{7}\right.$ and $1 \times 10^{9}$ cells $\left./ \mathrm{mL}\right)$ and the reaction time (24, 48 and $\left.67 \mathrm{hrs}\right)$.

\section{Extraction of metabolites}

The cells in the culture media were sonicated for $5 \mathrm{~min}$ and extracted with an equal volume of dichloromethane. The extract was dried over anhydrous $\mathrm{Na}_{2} \mathrm{SO}_{4}$ and concentrated under reduced pressure.

\section{Identification of obtained products}

The obtained products were analyzed by TLC, GC, GCMS, GC-GC.

Gas chromatography was carried out in a HEWLLET PACKARD 5890 serie II equipped with a FID detector and a CARBOWAX capillary column $(25 \mathrm{~m} \times 0.25 \mathrm{~mm}$ of internal diameter). Temperature program: $60^{\circ} \mathrm{C} / 8 \mathrm{~min}, 60$ to $210^{\circ} \mathrm{C}$ at $3^{\circ} \mathrm{C} / \mathrm{min}$; injector temperature $240^{\circ} \mathrm{C}$, detector temperature $250^{\circ} \mathrm{C}$; carrier gas: $\mathrm{He}, 2 \mathrm{~mL} / \mathrm{min}$; injection system: split (ratio 1:50). Internal standard: limonene oxide. The data was analyzed with the EZChrome software.

HRGC-MS was carried out in a Shimadzu QP 5050 in the same conditions mentioned above. The identifications were completed by comparison of mass spectra with literature (Adams, 2001).

The optical purity was determined in a GC-GC Shimadzu GC 17A. The first GC is equipped with a SE52 column and the second one with a modified $\beta$-ciclodextrin chiral capillary column. Temperature program: $50^{\circ} \mathrm{C}(6 \mathrm{~min}), 50$ $90^{\circ} \mathrm{C}$ at $2^{\circ} \mathrm{C} / \mathrm{min}, 90^{\circ} \mathrm{C}(20 \mathrm{~min}) ; 90-180^{\circ} \mathrm{C}$ at $2^{\circ} \mathrm{C} / \mathrm{min}$, $180^{\circ} \mathrm{C}$ (10 min); injector temperature $250^{\circ} \mathrm{C}$; detector temperature $280^{\circ} \mathrm{C}$; carrier gas: $\mathrm{He}$; injection system: split (ratio 1:150).

\section{Reagents}

1,8-cineole was provided by the Center of Agroindustrial Technology of Cochabamba, Bolivia.

Limonene Oxide: Aldrich, 97\%.

\section{RESULTS AND DISCUSSION}

During the initial screening three biotransformation products were detected and identified as 2-endo-hydroxy1,8-cineole, 2-exo-hydroxy-1,8-cineole and 2-oxo-1,8cineole (Figure 1).

Chiral GC analysis indicated that all these compounds are optically pure.

In order to optimize biotransformation parameters to obtain the best percent conversion we analyzed two variables. First, the influence of the inoculum's size was analyzed and it was found that the best conversion is achieved for the larger inoculum's size, being 2-endo-hydroxy-1,8-cineole the major product obtained (Figure 2).

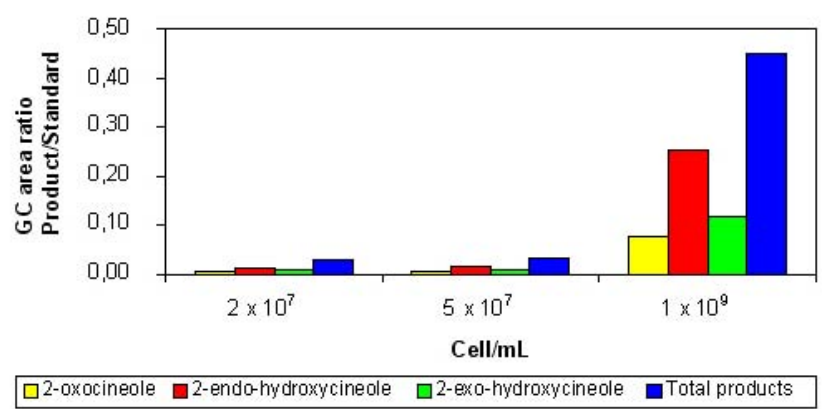

Figure 2. Influence of the inoculum's size on the biotransformation yield and product composition.

We also analyzed the effect of the reaction time on the biotransformation yield and product profile. These studies were conducted using the larger inoculum's size from the previous assay, and following the production of biotransformation products at different reaction times. The results indicate that the better yield is obtained at $24 \mathrm{hrs}$, with 2-endo-hydroxy-1,8-cineole accounting for $56 \%$ of the total product (Figure 3). 
$0-931710-85-5$.

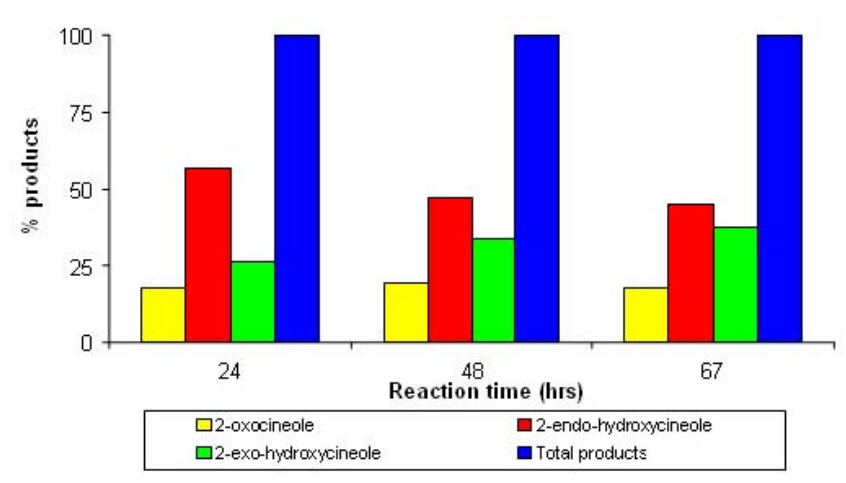

Figure 3. Evolution of the biotransformation product profile as a function of time.

Table 1 summarizes the best results obtained with the Rhodococcus sp. strain isolated by our group as well as previous reports with other strains of bacteria, including a Rhodococcus sp. strain. The Rhodococcus sp. strain isolated by our group presents a major percent conversion that the strain described before; although it produces a third metabolite. An important feature of the biocatalyst described in this paper is the stereo selectivity, since only one enantiomer of each product is obtained.

\section{CONCLUDING REMARKS}

A Rhodococcus sp. strain capable of metabolizing 1,8cineole was isolated from soil beneath Eucalyptus sp. Three compounds were obtained from the biotransformation of 1,8-cineole with this strain and they were identified as 2endo-hydroxy-1,8-cineole, 2-exo-hydroxy-1,8-cineole and 2-oxo-1,8-cineole. Chiral GC analysis indicated that these three compounds were optically pure. The biotransformation conditions were optimized to reach $98 \%$ bioconversion with this strain, what represents a better percent conversion than those previously reported for the biotransformation of 1,8-cineole with other bacterial strains. Despite this advantage, our strain shows low stereo selectivity since both the 2-endo- and the 2-exo-hydroxy1,8-cineole are produced and conditions should be optimized to achieve only one stereoisomer.

\section{ACKNOWLEDGMENTS}

The authors wish to thank Dr. Carmen Rossini and Dr. Andrés González for technical support. They also want to thank Bach. Daniel Lorenzo and Dr. Eduardo Dellacasa for chiral GC analysis.

\section{REFERENCES}

ADAMS, Robert P. Identification of essential oil components by gas chromatography/mass spectroscopy. Carol Stream; Allured Publishing Corp., 2001, 456 p. ISBN
ASAKAWA, Yoshinori; MATSUDA, Reiko; TORI, Motoo and HASHIMOTO, Toshihuro. Preparation of biologically active substances and animal and microbial metabolites from menthols, cineoles and kauranes. Phytochemistry, November 1988, vol. 27, no. 12, p. 3861-3869.

CARMAN, Raymond M.; MACRAE, Ian C. and PERKINS, Micael V. The oxidation of 1,8-Cineole by Pseudomonas flava. Australian Journal of Chemistry, 1986, vol. 39 , no. 11 , p. 1739-1746.

CLARK, George. Eucalyptol. Perfumer and Flavorist, May/June 2000, vol. 25, no. 3, p. 6-16.

FABER, Kurt. Biotransformations in organic chemistry - A textbook. $2^{\text {nd }}$ ed. Berling-Heidelberg-New York; SpringerVerlag, 1995. 356 p. ISBN 3-540-58503-6.

FOOD AND AGRICULTURE ORGANIZATION (FAO)CORPORATE DOCUMENT REPOSITORY- FORESTRY DEPARTMENT, Eucalyptus oil. In: Non-Wood Forest Products - 1, Flavours and fragrances of plant origin. Rome, Italy. Publications Division, Food and Agriculture Organization of the United Nations, 1995, vol.1, p. 111.

GENTA, M.T.; VILLA, C.; MARIANI, E.; LOUPY, A.; PETIT, A.; RIZZETO, R.; MASCAROTTI, A.; MORINI, F. and FERRO, M. Microwave-assisted preparation of cylicketals from a cineole ketone as potential cosmetic ingredients: solvent-freesynthesis, odour evaluation, in vitrocytotoxicity and antimicrobial assays. International Journal of Pharmaceutics, January 2002, vol. 231, no. 1, p. 11-20.

GUENTHER, Ernest. The Essential Oils, vol. II. Malabar, Florida; Robert E. Krieger Publishing CO., INC., 1975, 852 p. ISBN 0-88275-073-9.

LAWRENCE, Brian M. Progress in Essential Oil Research. 1,8 Cineole rich Eucalyptus Oils. Perfumer and Flavorist, January/February 1997, vol. 22, no. 1, p. 49-51.

LIU, Wei-guo and ROSAZZA, John P.N. Stereospecific hydroxylation of 1,8-Cineole using a microbial biocatalyst. Tetrahedron Letters, 1990, vol. 31, no. 20, p. 2833-2836.

MINISTERIO DE GANADERIA AGRICULTURA Y PESCA (MGAP) - Dirección General Forestal, Montevideo, Uruguay. Boletín estadístico [online]. Diciembre 2004, año 4, no. 3 [cited March 3, 2005]. Available from Internet: http://www.mgap.gub.uy/Forestal/Boletin\%20estad\%C3\% ADstico2004.pdf.

ROBERTS, Gareth A.; GROGAN, Gideon; GRETER, Andy; FLITSCH, Sabine L. and TURNER, Nicholas J. 
Identification of a New Class of Cytochrome P450 from a Rhodococcus sp. Journal of Bacteriology, July 2002, vol. 184 , no. 14, p. 3898-3908.

ROMAGNI, J.G.; ALLEN, S.N. and DAYAN, F.E. Allelopathic effects of volatile cineoles on two weedy plant species. Journal Chemical Ecology, January 2000a, vol. 26, no. 1, p. 303-313.

ROMAGNI, Joanne G.; DUKE, Stephen O. and DAYAN, Franck E. Inhibition of plant asparagine synthetase by monoterpenecineoles. Plant Physiology, June 2000b, vol. 123 , no. 2 , p. $725-732$.

WILLIAMS, Roger D.; TRUDGILL, Peter W. and TAYLOR, David G. Metabolism of 1,8-cineole by Rhodococcus species: Ring cleavage reactions. Journal of General of Microbiology, 1989, vol. 135, no. 7, p. 19571967. 